\title{
Eating à la Criolla : Global and Local Foods in Argentina, Cuba, and Mexico
}

Comer à la Criolla: La cocina global y local en Argentina, Cuba, y México

Manger "à la criolla »: les cuisines internationale et locale en Argentine, à Cuba et au Mexique

Jeffrey M. PILCHER

\section{(2) OpenEdition}

Journals

Édition électronique

URL : https://journals.openedition.org/ideas/406

DOI : 10.4000/ideas.406

ISSN : 1950-5701

Éditeur

Institut des Amériques

\section{Référence électronique}

Jeffrey M. PILCHER, «Eating à la Criolla : Global and Local Foods in Argentina, Cuba, and Mexico », IdeAs [En ligne], 3 | 2012, mis en ligne le 13 décembre 2012, consulté le 20 octobre 2022. URL : http:// journals.openedition.org/ideas/406 ; DOI : https://doi.org/10.4000/ideas.406

Ce document a été généré automatiquement le 20 octobre 2022.

\section{(c) (†) $\odot$}

Creative Commons - Attribution - Pas d'Utilisation Commerciale - Pas de Modification 4.0 International - CC BY-NC-ND 4.0

https://creativecommons.org/licenses/by-nc-nd/4.0/ 


\title{
Eating à la Criolla : Global and Local Foods in Argentina, Cuba, and Mexico
}

\author{
Comer à la Criolla : La cocina global y local en Argentina, Cuba, y México \\ Manger " à la criolla »: les cuisines internationale et locale en Argentine, à Cuba \\ et au Mexique
}

Jeffrey M. PILCHER

The author wishes to thank Donna Gabaccia, Domingo García-Garza, José Moya, Rebekah Pite, and the anonymous readers for their thoughtful suggestions.

\section{Introduction}

1 Arnold Bauer centered his study of Latin American material culture on the historical tension between local and global goods. In seeking to periodize these conflicting influences, he observed that both nineteenth-century liberalism and twentieth-century populism had culinary expressions (Bauer, 2001). Fin-de-siècle liberal oligarchs consumed French haute cuisine as part of a wider pursuit of western modernization, while a few decades later, radical and revolutionary politicians rejected foreign affectations and instead sought to define local foods as national cuisines, often identifying them with the term "criollo" (creole). Although I followed this same chronology in a study of Mexican food (Pilcher, 1998), recent research has revealed more complicated patterns of culinary globalization and localization across the history of modern Latin America (see, for example, Juárez López, 2008 ; Bak-Geller Corona, 2009 ; Milanesio, 2010). This essay examines these patterns with particular attention to the meanings of criollo in the culinary literature and practices of Argentina, Cuba, and Mexico. It concludes that national cuisines emerged throughout Latin America not from the rejection of the global in favor of the local but rather through a blending of 
the two in a culinary sensibility that combined patriotism and cosmopolitanism in pursuit of social distinction.

2 As Bauer observed, the provenance of rare goods has served as a source of prestige and power for those with the wealth to possess them. Medieval lords demonstrated their lofty status by consuming spices from distant lands, fabulous animals like peacocks, or simply fresh fruits and vegetables during a long, cold winter. With the conquest of the Americas, imperial goods from Europe and spices from Asia were valued more highly than indigenous ones, although a few foods of the local nobility such as chocolate retained their prestige under Spanish rule. Moreover, these connotations of local and global have changed over time, as imported foods become naturalized in local soils, and as familiar domesticates gain exotic new meanings through association with outsiders, for example, French fries in Peru. Local foods have recently acquired new cachet with the rise of a global food system that could transport foods off-season harvests and with the hollowing out of local agriculture in the developed world. Thus, farmers' markets became trendy when actual farmers were becoming rare (Bauer, 2001 ; see also Wilk, 2006 ; Freedman, 2008).

3 The unstable meanings of the local within Latin American are also apparent in the etymology of the term "criollo," as described by the linguist José Juan Arrom (1951). Deriving from the root "criar" (to raise), it came to mean a person of European or African ancestry born in the Americas. What gave the term significance was the concern with how the New World environment and food had the potential to physically transform its inhabitants, a point that has been examined carefully by Rebecca Earle (2012). Criollos were thus considered distinct from, and often inferior to, Europeans or Africans born in the old World. Demands for autonomy gave rise to a form of criollo patriotism among local notables who challenged the domination of peninsular officials and merchants. Once independence had been achieved in the nineteenth century, the meaning of criollo shifted away from a pan-American oppositional identity and came to indicate the national or local, regardless of its origins. Thus, ganado criollo may refer to cattle of old Spanish stock, transplanted to the Americas in the colonial era, whereas papas criollas simply indicate local varieties of potatoes. The term also acquired differing class connotation; as Ana Cara has observed, by the early twentieth century, "what was criollo was either romanticized and idealized or considered backward and interfering with progress" (2003: 39). Yet these local meanings also differed across countries. In Mexico, the term became associated more with a privileged elite of white "founding fathers," whereas in Argentina, criollo was identified largely with a rustic gaucho society.

4 To avoid the particularistic meanings adopted within any single nation, and to account for the global circulation of people, ideas, and goods, it is important to examine these culinary discourses from a broad comparative perspective. The three nations considered here offer a useful sample illustrating the social and economic diversity within Latin America. Argentineans have cultivated a European identity and their contemporary agriculture is in many ways quite similar to that of the United States. Cuba has come to be seen as a prototype of tropical plantation agriculture founded on slave labor. Mexico is considered to be a mestizo society with subsistence farms coexisting alongside commercial latifundia. Yet these contemporary images have been shaped by the modern nationalist imagination for political purposes. African slaves and nomadic Indians made up a considerable part of the Argentine population as late as the 
nineteenth century, although they have largely vanished from the historical memory with more recent European immigration. Cuba, by contrast, had a white majority in the nineteenth century and was more urbanized than England and the Netherlands by the early nineteenth century (Moya, 2006).

The nature of literary production within the culinary realm also offers an important point of comparison. Priscilla Parkhurst Ferguson (2004) has defined cuisine as a discursive practice, a public and contested cultural code that formalizes everyday cooking practices into stable patterns, thereby creating the basis for collective identities. Cookbooks have constituted part of the mass literature that enables the formation of national identities, and a deeply important one at that, precisely because it draws on the deeply affective bonds of food and yet they are often overlooked. The three countries surveyed here are exceptional within Latin America for the volume of works they produced. Comparative analysis of their usages of the global and the local reveals the interactions between domestic discourse and larger political trends, a point also demonstrated in a recent study by Donna Gabaccia and Jane Aldrich (2012).

Two moments were particularly important in defining these national cuisines and the larger nationalist discourses : the liberal oligarchies of the late-nineteenth century and the populist revolutionaries of the mid-twentieth centuries, who often defined themselves in opposition to their European-oriented predecessors. The producers of culinary literature in each of these three countries deployed the term criollo - or at times significantly avoided it - as a way of asserting their own distinction on both global and national stages.

\section{The Liberal Oligarchy Eats Local}

7 In the second half of the nineteenth century, after decades of instability, cliques of liberal-minded elites consolidated power in many Latin American nations and set the stage for export-led economic growth, if not development. Turning their back on the declining Spanish empire, these leaders oriented themselves with the ascendant North Atlantic powers of Britain, France, and the United States. Liberal intellectuals sought to claim a place at the table of civilized nations by importing fine wines, canned truffles, and other consumer goods, as well as by reading the latest cookbooks, newspapers, and novels. All of these purchases were paid for through raw material exports to the industrial powers. Yet these dreams of westernization were tempered by elements of criollo patriotism ; although local foods were often looked down on by Europeans, they held a nostalgic and folkloric attraction, even for foreign-educated elites. These criollo sentiments were expressed differently in each country, and appeared most strongly in Cuba, precisely because it remained a colony of Spain throughout the nineteenth century.

8 Criollo patriotism took shape in Mexico in the late colonial era, when American-born elites acquired a distinct identity in opposition to peninsular Spaniards, on the one hand, and to the indigenous and mixed-race lower classes, on the other. Criollo patriots in Mexico resisted peninsular domination by insisting on the greatness of pre-Hispanic civilizations and the wisdom of Aztec emperors. Rejecting the traditional justifications for the Spanish conquests, they sought to establish themselves as legitimate successors to older empires in the Americas, even as they kept their distance from the actual descendants of the Aztecs. Criollo affections for a pre-Hispanic past were more 
tempered elsewhere in the hemisphere, especially after the bloody rebellion that broke out in Peru in 1780 under the banner of the last Inka, Tupac Amaru (Florescano, 1994; Brading, 1991 ; Rodríguez, 1998).

9 Foods were particularly freighted with racial meaning. In the early colonial era, eating indigenous food was considered to be positively dangerous, and conquistadors feared that if they ate Indian foods they would descend to the level of the Indians. Nevertheless, early efforts to replace the indigenous diet with European foods were largely a failure, both because natives retained their taste preferences and because indigenous staples were better suited to local environments and more productive, although old World livestock did assume a prominent role in the diet. Criollos spent large sums to import Mediterranean foods, but local dishes did enter the diet on the margins, for example, chocolate and chiles, frijoles and fruits. The importation of European cuisine was particularly pronounced in the viceregal courts of Mexico City and Lima, where aristocrats imported luxury foods and foreign chefs to preserve their status within early modern social hierarchies. This is not to say that Spanish migrants and their descendants never ate the local staples of maize, cassava, and potatoes, but doing so was an indication of downward social mobility (Earle, 2012).

Cosmopolitan influences on Mexican cuisine took root in the late colonial era ; they grew steadily through the nineteenth century; and they flowered spectacularly under the modernizing regime of General Porfirio Díaz (1876-1911). After the Bourbon dynasty claimed the Spanish throne in 1700, French and Italian chefs and bakers became even more prominent in Mexico City, while even provincial capitals such as Chihuahua City boasted French bakers, often of Basque origin. The influx of foreigners continued following independence in 1821. The French intervention of 1838 was dubbed the "pastry war" when it became known that the causus bellus included the damage claims of a patisseur, whose shop had supposedly been ransacked by revolutionaries a decade earlier. By the 1840s, foreign travelers and local journalists noted the presence of French chefs in aristocratic households and pretentious hotels. A second French invasion, in 1862, briefly installed the Austrian archduke Maximilian as emperor of Mexico ; his court set the model for fine dining. Although the French army was soon expelled by liberal troops under the command of General Díaz, French chefs continued to find steady employment throughout his long presidency in elite homes, elegant restaurants, and exclusive clubs.

11 Notwithstanding this foreign infatuation, Mexican culinary literature sought to unify the nation around local foods, at times in opposition to European tastes. Admittedly, the two most prominent works, El cocinero mexicano and the Novísimo arte de cocina, both published originally in 1831 and revised throughout the nineteenth century, included countless foreign dishes. These recipes were generally translated from French cookbooks, although there is considerable evidence that Mexican cooks altered the recipes to fit local tastes. Regardless, these volumes laid out a clear image of a distinctively Mexican cuisine based on local dishes such as mole de guajolote, a rich turkey stew blending Asian spices with indigenous chile peppers and chocolate. $\mathrm{El}$ cocinero adopted a particularly strident nationalist tone, insisting on the sophistication of Mexican taste, despite the incompatibility of chiles and spices with European Enlightenment culinary ideal of "natural" flavors (Pilcher, 1998 ; Bak-Geller Corona, 2009). 
12 of the nineteenth century, sought to define Mexican cuisine. Given the pronounced regional nature of the cuisine, these volumes gave relatively few geographical references, with Puebla and Oaxaca as the most common indications. Scholars have begun to examine why particular places gain reputations for culinary excellence, and this provides an interesting case study. Puebla is considered as the criollo city par excellence, unlike Mexico City, which is remembered as the site of the Aztec capital, Tenochtitlan. The Catholicism for which Poblanos are also renowned gained culinary expression through the sweet products of convent kitchens, particularly the custards and conserves of Arabic origin. Oaxaca, by contrast, has come to be known as a center of indigenous life, based on the diverse Indian groups living in the state. However tempting it is to see Puebla and Oaxaca as a criollo-indigenous culinary pole for Mexico, the nineteenth-century recipes that represent Oaxaca are more often associated with the criollo elite, the heavily spiced mole negro (black chili sauce) rather than the simpler and more indigenous verde (green), and the convent sweet turrón de Oaxaca (nougat).

Other significant exclusions were also apparent in the foods and regions of the nineteenth-century national cuisine. The most notable omission was maize, the staple grain and gastronomic foundation of the indigenous peoples. Recipes do exist, but given their predominance in popular Mexican cooking, they are notable for their absence from the literature. Geographically marginal groups were also left out. The first Yucatecan cookbook was published already in 1832, laying out the distinctive flavors of that region, yet virtually no recipes from the famously separatist Yucatán appeared in central Mexican texts (Ayora Diaz, 2012). Recipes from northern Mexico likewise were ignored, despite view of the region as the most economically dynamic in the country. Culturally, it may have been considered suspect because of its proximity to the United States and nomadic Indians.

In addition to cookbooks, other literary genres and practices sought to define the national cuisine. One popular literary and artistic form that explored the nation was costumbrismo, a form of local color. Street vendors, kitchen scenes, and food descriptions were prominent within these works, but generally as a form of elite slumming, for example, enchilada makers in pulque shops (taverns serving an indigenous beer) as described by liberal intellectuals such as Guillermo Prieto (1906), Manuel Payno (2004), and Antonio García Cubas (1946). There were also moments when Mexican dishes appeared on the menu, although generally in private rather than on public occasions. While French cuisine reigned supreme in state banquets, the Oaxacanborn president served local specialties such as mole negro when entertaining at his private residence, Casa de Cadenas. The fabled kitchen of the Jockey Club likewise retained a cordon bleu (a woman skilled in domestic cookery), which in Mexico translated into a woman from Puebla to prepare mole for club members (Pilcher, 2012). Moreover, Jose Luis Juárez López has observed that the cookbooks published in the first decade of the twentieth century in Mexico had already begun to include a greater proportion of Mexican recipes, even before the outbreak of the Revolution of 1910 (2008: 90-94).

15 Although Mexican elites centered the national cuisine on criollo dishes, they rarely used that word to describe it. What criollo meant in gastronomical terms corresponds to Enrique Florescano's historical description of criollo patriotism as an appropriation of indigenous political histories by an elite of European descent, while carefully 
separating out the living Indians (1994). A prominent example of this can be seen in Manuel Payno's literary masterpiece, Los bandidos de Río Frío (1891). At an early moment in the novel, he described rival banquets held half a century earlier in honor of the national saint, the Virgin of Guadalupe. While the lower classes ate chito (fried goat), salsa borracha (pulque sauce), and tacos of avocado, a presidential banquet consisted of more refined local dishes, carefully distinguished from the French cuisine that was fashionable during the Porfirian era. The dishes included bread soup, stuffed chiles, beef tongue, two versions of mole, and sweets from the colonial convents. Payno's description of the meal perfectly fits Florescano's description of criollo patriotism as a combination of Hispanic pucheros and Aztec festival dishes.

Although Payno was still basically sympathetic to the foods of the lower classes, many of his contemporaries were quite dismissive of the indigenous cooking (Juárez López, $2008: 69-70)$. Liberal elites even attributed Mexico's failure to develop to the poor diet of the lower classes, arguing spuriously that maize was nutritionally inferior to wheat, a "tortilla discourse" that at least avoided the racist connotations of social Darwinism favored in Anglo-American intellectual circles (Pilcher, 1998).

One element that has not been given sufficient credence in discussions of Mexican national cuisine has been the interplay between foreigners and criollo exiles in imagining this national cuisine. Sarah Bak-Geller Corona (2009) has revealed the crucial role of Parisian publishing houses in the production of Mexican culinary literature, which not only ensured the accurate translation of French recipes into Spanish, but also sought to elide Mexican with American more generally, the better to increase market share in other countries. A revealing example of the effects of exile can be found in the wife of a conservative general, Concepción Lombardo de Miramón, who became depressed while in exile in Paris : "I am crying for the Alameda of Mexico [City], which perhaps I will never see again, for our Mexican cuisine, for our chiles, and for our tortillas." Nevertheless, she confessed that "when I was in my country, I neither went for promenades in the Alameda, nor frequently ate Mexican dishes" (1960:332). The national cuisine was therefore situational. Porfirian aristocrats displayed their cosmopolitanism to win the respect of foreigners or to snub the aspiring middle classes, but still held a great affection for the local foods of their youth.

In Argentina, the tension between the global and the local was even more formative to the political struggles of the nineteenth century. Liberal intellectual and future president Domingo Fausto Sarmiento framed this national dilemma as a conflict between "civilization and barbarism" - the title of his nationalist manifesto of 1845. For Sarmiento, civilization came with the spread of European cities, while barbarism lay among the gauchos, the mixed-race cowboys who roamed the vast grassy plains of the pampas. Sarmiento composed this book in exile during the government of Juan Manuel de Rosas, a caudillo (warlord) and wealthy landowner from the province of Buenos Aires, who dominated Argentine politics from 1829 until his defeat and exile in 1852. National unification came only a decade later, in 1862, but a new constitution and the military expulsion of nomadic Indians set the stage for liberal oligarchs to become rich on the agricultural exports from the pampas.

Although the gauchos were marginalized by wheat farms and cattle feedlots worked by Italian and Spanish migrants, the struggle between cosmopolitanism and local culture remained a central theme in Argentine national discourse. Despite the nostalgic vision conveyed by José Hernández's epic poem, El gaucho Martín Fierro (1872), the 
civilizational conflict formulated by Sarmiento has remained the basis for social distinctions between more recent immigrants and old stock criollos, with the latter often looked down on as backward and poor (Ruggiero, 1993). Yet the locals refused this dichotomy, believing that their ancestors had grown strong on a diet of beef, unlike ill-fed peasants arriving from the southern European countryside. José Moya quoted a mocking Porteña description of a Spanish immigrant as the product of "three generations of Galician tuna pies" (1998 : 372).

Argentine cuisine became progressively more cosmopolitan with the growth of trade and immigration in the nineteenth century, particularly in the city of Buenos Aires. Created only in 1776, the Viceroyalty of La Plata never acquired a noble court to comparable to those of Mexico City or Lima. Nevertheless, the celebrity chef of the era, an Englishman who went by the name of Monsieur Ramón, opened a culinary academy to teach slaves how to cook the latest European foods. He also ran a coffeeshop, one of only three public dining spots in the city, along with the Fonda de los Tres Reyes and a Confitería francesa (Furlong, $1969: 353$; Arcondo, 2002 : 125, 159). By the end of the nineteenth century, however, there was no shortage of foreign cooks ; for example, an 1890 cookbook compiled by Juana Manuela Gorriti attributed a recipe for macaroni a la Caprese to a Neapolitan cook working in Buenos Aires named Catalina Pardini (Gorriti, 1999 : 195-96).

Meanwhile, distinctive local culinary traditions were taking shape in the provinces, as was documented by the social historian Aníbal Arcondo. Using travel accounts, he noted that criollos generally dressed their food in the Spanish fashion, albeit with the local flavoring of chile. In the plains south and west of Buenos Aires, asado (grilled beef) was the most important food, often cooked with the skin still on, a convenient way of protecting the meat from the fire. In the so-called Mesopotamian provinces of the northeast, the regional cuisine was inflected with dishes from neighboring Brazil and Paraguay, including the consumption of cassava. Horticulture predominated in the foothills of the Andes in provinces such as Cordoba and Mendoza, where maize and chile were common foods. In addition to grilled meat, Arcondo listed puchero, empanadas (turnovers), and carbonadas (beef and vegetable stews) as the preeminent nineteenth-century criollo dishes (2002 : 110, 185, 190-91).

African ingredients and cooking techniques also became part of the criollo repertoire, since people of African descent constituted the majority of servants in Independenceera Buenos Aires, as well as prominent vendors of bread, vegetables, and empanadas. Arcondo noted, for example, a variety of squash called "zapallo de angola" (2002:110, 123). The archaeologist Daniel Schávelzon (2000: 71) attributes the origins of Argentine locros (stews) to distinctive African earthenware cooking pots. Comparative research may turn up further influences, such as an illustration of a rural couple from the midnineteenth century which shows the woman with a tree-trunk mortar (pilón) and narrow, elongated, double-headed pestle, a distinctively West African technology for rice milling that was diffused widely through North and South America by the African diaspora (Cicerchia, 1998 : 122 ; see also Carney, 2001).

Culinary literature, cosmopolitan by nature, used the term criollo somewhat hesitantly in the late nineteenth century. This was an era of rapidly growing migration, when foreign influences were seen as a boon to the nation (Remedi, 1998 : 185 ; Arcondo, 2002 : 248-51, 294.) For example, Gorriti's Cocina ecléctica brought together recipes from her literary acquaintances from South America and as far away as Mexico City, New York, 
and Paris (Scott, 1997). Despite these global influences, the work did make references to local dishes, including churrascos (grilled beef), drawn from "those who possess the secrets of preparing meat, the gauchos" (Gorriti, $1999: 234$ ). Nevertheless, the only recipes explicitly labeled criollo were from Peruvian contributors : a lomito (pork loin) and a tamal limeño, labeled as the "delicious product of the criolla cuisine of Lima" (Gorriti, 1999 : 73).

Other early cookbooks likewise made few references to criollo foods, although their importance increased over time. In 1889, chef Francisco Figueredo published perhaps the first native volume, El arte culinario (1889). Although his birthplace is unknown, Figueredo had worked in Montevideo and Rio de Janeiro before arriving in Buenos Aires around 1871. Not surprisingly, French cuisine predominated among his recipes, although he did make attempts to localize these recipes. For example, he served a soup dedicated to the "Triple Alliance" of the Paraguayan War to General Mitre in 1873. A second early volume was La perfecta cocinera argentina, originally published in 1890 by Teófila Benavento, a pseudonym for Susan Torres de Castex, the wife of a leading Buenos Aires doctor. Both volumes contained recipes for dishes such as asado, puchero, locro, empanadas, and humitas (tamales), that would become accepted as Argentina's criolla cuisine (Arcondo, 2002 : 225-26). An "asado criollo" also provided an occasion for a picnic by an Anarchist, Communist Youth Group, as advertised in the radical newspaper El Perseguido in 1892. Thus, even anti-nationalist immigrants appreciated the improved standards of living that made it possible for workers to afford a beef barbecue.

The meanings of criollo were different in Cuba, in part because of its delay in achieving independence. During the middle years of the colonial era, the Caribbean was generally a backwater, with smallholders subsisting on indigenous root vegetables, cattle raising, and swampland rice culture. The British occupation of Havana during the Seven Years' War gave renewed energy to the sugar industry, through the importation of slaves and modern technology. The Haitian revolution of 1791, which started a chain of abolition movements, further boosted the industry. With a large slave population, Cuban elites showed little interest in the revolutionary movements that flourished elsewhere in Latin America. Those who were dissatisfied with Cuban rule were more apt to hope for annexation to the United States as a slave state. This dream faded with the Civil War in the 1860s, and shortly thereafter the first Cuban independence war broke out, the Ten Years' War (1868-1878).

Cuban elites expressed their cosmopolitan impulses through affiliation with both Spain and the United States. After the loss of their other colonies, Spaniards hoping to "make the Americas" to get rich in the colonies were limited to Cuba and Puerto Rico. Fanny Calderón de la Barca, during her visit to the island in 1839, declared the foods to be essentially Spanish (1966). As the wife of a Spanish minister, it was only natural that she would be treated to such dishes, but the wealth from sugar and coffee exports allowed planters and merchants to import large quantities of peninsular luxury foods (Dawdy, 2002 : 56). At the same time, however, Cubans also began to develop connections with their rising neighbor, the United States. Merchants established offices in New Orleans, New York, and other important ports, while planters sent their children to the U.S. for education. These nascent Cuban American communities established grocery stores and restaurants to supply their nostalgic desire for Antillean foods, while at the same time acquiring a taste for Anglo foods as well (Pérez, 1999). 

embracing a criollo identity, reflecting intellectual currents of mid-nineteenth century that viewed the islands as an outpost of colonialism in a hemispheric of republics. Particularly for those who were excluded from wealth and political office by the influx of peninsulars, a desire for separation from Spain had become strong. The literary circle of Domingo del Monte was a particularly important group in the formation of these attitudes. Active from 1835 until del Monte was arrested for conspiracy in 1844, the group developed works of costumbrista literature that viewed the local and folkloric in a romantic light. This movement also contained a strong anti-slavery tendency, and this literature was favorable to Africans and indigenous people. Cuban culinary literature, beginning in the mid-1850s, was a product of this local sentiment, even while embracing French gastronomy. The first of these works, the Manual del cocinero cubano y español (1856), was published by Eugenio del Colmo y Garces, who in addition wrote domestic literature and almanacs, including a guide to planting tobacco. Unfortunately, I have been unable to consult this volume. A revised version of it, however, was put out the following year as the Nuevo manual del cocinero cubano $y$ español (1857), by J. P. Legran, a chef at a Havana restaurant. Another work, the Nuevo cocinero catalan y cubano (1858), was published by Juan Cabrisas, also a restaurant chef. A final, slimmer volume appeared in 1862, El cocinero de los enfermos, manual de cocina cubana, but the outbreak of the Ten Years' War a few years later put an end to this gastronomic flourishing. Given the work of these chefs, it is unsurprising that most of the recipes were for Spanish dishes.

Although chefs understandably included cosmopolitan recipes, these works are striking for the predominance of local dishes and the explicit way that they defined a criollo cuisine. This category amounted largely to the presence of viandas, a category of starchy indigenous roots, including yucca, potato, sweet potato, boniato, chayote, and malanga. Criollo also embraced foods of African origin, including okra, plantains, and yams. However these vegetables had been localized so thoroughly that few may have seen them as anything but Cuban. Ultimately, the word probably indicated the adaptation of European foods to local ingredients. For example, lengua a la criolla (creole beef tongue) was sauced with a typical European mix of parsley, onion, mint, oregano, pepper, pimenton, and capers, but garnished with fried guinea plantain (Legran, 1857 : 22). Moreover, there was far greater awareness of the geographical specificity than in the works of either Mexico or Argentina, despite the small size of the island. Legran, in particular, distinguished between the styles of Havana, Matanzas, east of the capital, Pinar del Rio, to the west, Puerto Principe (Camaguey), as well as tierra adentro (inland) and guajiro (campesino style). The Catalan volume of Cambrisas was less specific, but also contained numerous dishes cooked a lo criollo (Cabrisas, 1858).

Thus Cuban authors voiced a nascent national identity in culinary form at a time when imperial censors prevented other forms of patriotic expression. Such local awareness was all the more remarkable because of the presence of considerable ambivalence about the nutritional value of viandas, and a firm belief in the importance of European bread, even when wheat was imported at great expense. Shannon Lee Dawdy has observed that the newspaper El Siglo ran editorials in the 1860s voicing such sentiments, anticipating the Mexican "tortilla discourse" by several decades (Dawdy, 2002 : 53). The inclusiveness of this vision of the Cuban criollo is also striking in comparison with contemporary counterparts in Argentina and Mexico. 

opposition to Spanish colonial domination. Nevertheless, the liberal ideals of export capitalism and western modernization did not completely preclude the development of local forms of cultural nationalism based on long-scorned foods of the lower classes. This culinary nationalism likely arose from a combination of the desire to claim unique ties to the patria and from love of familiar childhood foods, however unfashionable they may have seemed to foreigners. Political upheavals of the twentieth century eventually enshrined these same foods into still more explicit national cuisines, but the ambivalence already apparent in the nineteenth century would continue to temper the embrace of local foods.

\section{The Cosmopolitan Side of Revolutionary Nationalism}

Around the time of World War I, many of the formative elements that shaped nineteenth-century Latin American national ideologies were reversed in dramatic fashion. European trench warfare devastated the continent's image as a model of civilization and progress. Avant-garde intellectuals in Latin America responded by seeking inspiration in the indigenous past, particularly during moments of revolutionary populism, which swept through all three countries irregularly during the twentieth century. The nationalist impulse of these revolutionary movements was not limited to cultural expressions but also included attempts to assure more equitable food distribution, in part to create healthier and more productive populations. Implementing such policies often entailed curtailing the food exports that had enriched the old liberal oligarchies. Although local foods were valorized under the label of criollo or indigenista, revolutionary middle classes sought to assure their social distinction by the pursuit of cosmopolitan cuisines. Even before the rise of neoliberalism in the late twentieth century, global foods remained central to a sense of social distinction in each of these countries.

In Mexico, after the dictator Porifiro Diaz was overthrown by campesino armies in 1911, an authoritarian ruling party took shape using revolutionary social reforms to claim political legitimacy. President Lázaro Cárdenas (1934-40), in particular, carried out a wide-ranging program of land distribution, helping to provide rural workers with access to land, the lack of which had been the most important cause of malnutrition in the nineteenth century. The government also decreed indigenista policies intended to draw Indians into the national life. Already in 1909, Andrés Molina Enríquez had refuted the tortilla discourse, challenging the notion of wheat's superiority and declaring maize to be "in an absolutely indubitable manner the national cuisine" (1978 : 279). Indeed, when the National Institute of Nutrition conducted scientific studies of the national diet in the 1930s, they found maize to be just as nutritious as wheat. Artists and intellectuals also took up the cause of indigenous foods ; Frida Kahlo, for example, served local foods from indigenous markets to the radical artistic circle. A culinary mythology was also fabricated, based on figures such as the nuns of Puebla, in part to encourage internal tourism (Pilcher, 1998 ; Juárez López, 2008).

Government policy continued to have a pronounced urban bias, seeking to draw campesinos off the land to provide labor for industrialization. Enrique Ochoa (2000) has examined an elaborate state welfare bureaucracy that developed around food in the mid-twentieth century. Although begun under the reformist presidency of Cardenas, 
the agency was intended not to support small farmers but rather to provide subsidized food to urban workers, another important constituency of the regime. Thus, large scale purchases focused on wheat, rather than corn, and concentrated among large producers in the northwest. The interests of smallholders dwindled even further as conservative administrations came to office during and after the Second World War. When the state food agency did seek to alleviate rural poverty, it did not promote the indigenous staples of maize and beans but rather industrial foods such as milk and animal crackers. A recent study by Sandra Aguilar-Rodríguez (2011) has found that attempts to increase milk consumption were the product of racially charged medical discourses imported from Europe and the United States by Mexican nutritional reformers, with little regard for local cultures and popular attitudes. This too reflected official indigenista ideology, which sought not to promote Indian culture per se, but rather a mestizo nationalism. Thus, many of the criollo dishes that Payno described in the nineteenth century became labeled in the twentieth century as "mestizo," a hegemonic term used to attempt to impose national cohesion on a highly stratified and antagonistic class structure.

The foremost interpreter of culinary nationalism at mid-century was Josefina Velázquez de León. With illustrious ancestors dating back to the conquest, she was born into a criollo family that had fallen on hard times after the Revolution, and became a cooking teacher to support herself and her family. In the early 1930s, her classes, articles, and cookbooks focused on European foods and novel imports from the United States, like decorated wedding cakes, although she also included basic Mexican dishes such as sopa de fideos (noodle soup). By the 1940s, however, as she traveled across the country giving cooking classes, she began to develop a more nationalistic vision, built around regional cuisines. When teaching cosmopolitan dishes to provincial women, she learned to cook their local favorites, collecting these recipes into a series of cookbooks dedicated to each state. She also published a landmark volume, Platillos Regionales de la República Mexicana (Regional Dishes of the Mexican Republic, 1946), which laid out a coherent vision of Mexican cuisine, featuring iconic local dishes (Pilcher, 1998).

Yet these regional specialties continued to compete with European and North American foods, at least among the affluent classes. Indeed, Velázquez de León has largely disappeared from the historical memory of Mexican cuisine, although a few of her most prominent works remain in print. Her neglect may in part result from her failure to become a media celebrity. Instead, it was people like Chepina Peralta who gained wide recognition as television cooks. Such a cosmopolitan approach continued into the final decades, as neoliberalism promoted culinary tourism. Beginning in the 1980s, the nueva cocina mexicana appeared as a distinctively Mexican haute cuisine. A "pre-Hispanic menu" was first pioneered at the Mexico City restaurant, Fonda Don Chon, by Fortino Reyes Contreras, who sought to reinterpret the festival foods of his home village in Puebla as restaurant fine dining. However, the version that eventually took shape in the cookbooks and restaurants of Patricia Quintana and other celebrity chefs owed more to the cosmopolitan techniques of the French nouvelle cuisine. Their goal of reinventing the cuisines of the ancient Mayas served as a perfect example of the colonial criollo project of appropriating histories of pre-Hispanic grandeur for an otherwise Eurocentric ruling elite (Pilcher, 2012). 

than armed revolution in 1916, when the Radical Party won the first presidential election held under universal manhood suffrage. Admittedly, its policies were far from radical, and in 1930 it too was overthrown, this time by a military revolt. Nevertheless, these upheavals had instilled a new populist tone to Argentine politics, which became even more pronounced with the rise of Juan Domingo Perón in 1946. There does not seem to have been much immediate culinary reaction to these political transformations. The trend toward criollo foods in cookbooks, begun in the late nineteenth century, continued in volumes published in the 1910s and 1920s, although these volumes often also included separate parts dedicated to a self-styled "cocina cosmopolita" (Arcondo, $2002: 232-33$ ).

ondeavors, food policy and concepts of Argentine cuisine were nationalized by the Perón regime. Natalia Milanesio (2010) has examined these changes in a formative article, noting that before the 1940s, food and nutrition were considered to be local issues, controlled by municipal governments. Peronista officials played on the masculine associations of the Argentine asado in creating an entitlement to beef for his working-class constituents, known as descamisados (shirtless ones), at the expense of British exports. The populist policies backfired, however, when droughts devastated the livestock industry around 1950. Dieticians put a brave face on the catastrophe by emphasizing the dangers of excessive beef consumption and calling for more fish and vegetables. The government even promoted criollo alternatives such as artisanal cold cuts and preserved sweets as a more traditional version of the national cuisine, but the shortage of beef and wheat bread undercut the regime's popularity with the masses.

The cosmopolitan counterpart to these multiple Peronista ideals of local food was defined by a culinary instructor and cookbook author named Doña Petrona Carrizo de Gandulfo. In a forthcoming study, Rebekah Pite examines the influence of Doña Petrona, a provincial migrant like Evita who built a career outside the home while simultaneously reinforcing the ideals of patriarchy and domesticity for other women. She began as a home economist in 1928 demonstrating appliances for a British gas company and published the first editions of her famous cookbook in the 1930s. El libro de Doña Petrona remains in print, having gone through more than a hundred editions, making it one of the best-selling works in Argentine history. Among the voluminous recipes, only a few bear the label criollo, which generally indicated a mixture of tomato, garlic, onion, parsley, oil, vinegar, and perhaps chile pepper, served as an accompaniment to roasts or stews. A few foreign dishes were also localized in this fashion such as pizza cooked a la criolla, which used this local mixture in addition to such Italian ingredients as anchovies, cheese, and black olives. The vast majority of her recipes were for cosmopolitan dishes, which appealed to upwardly mobile Argentines, including provincial women and immigrants. Unlike the work of Josefina Velázquez de León, she made few attempts to envision an ostensibly national cuisine. One of the rare references to Argentine history, a Russian salad served in aspic, was significantly named after Manuelita Rosas (Carrizo de Gandulfo, 1949 : 67-68, 157). Doña Petrona was also far more successful than her Mexican counterpart as a television personality, despite Argentine's disapproval of her imperious attitude toward an on-screen helper, which they considered to be inappropriate in a society where full-time servants no longer represented the reality of middle-class life (Pite, 2011). 
39 In modern Argentina, the culinary ideal of the criollo has become most firmly associated with the iconic asado. Anthropologist Jeffrey Tobin has explained how this practice represents a national symbol drawn from a particular region : Buenos Aires (and neighboring Uruguay). Although the gauchos of old consumed vast quantities of meat as a byproduct of animals whose export value was limited to hides and tallow, today only the wealthy can afford choice cuts of meat. Nevertheless, working-class cooks could prepare asados using chorizo, organ meats, and other inexpensive cuts. The asado is also exclusive in its gendering as a masculine phenomenon. According to one authority, only real men can appreciate grilled meat with al gusto, and the "asador criollo suffers when a woman eats a dainty portion" (Tobin, $2005: 213-14)$ ). In an increasingly urban society, the gaucho no longer signifies the barbarism of Sarmiento but rather a nostalgic repository of Argentine values. (For a similar phenomenon in northern Mexico, see Camou Healy, 1994.)

The relationship between the local and the global in twentieth-century Cuba has likewise been shaped by revolutionary history. The Cuban war of independence, launched by José Martí in 1895, was subverted by President William McKinley's declaration of war against Spain in 1898. The United States dominated the island politically and economically until the Fidel Castro Revolution of 1959. Nevertheless, the independent era began with optimism, when José Triay celebrated the expulsion of Spain by publishing a proudly criollo text, the Manual del cocinero criollo (1903), which was stripped of the Spanish and Catalan references of colonial cookbooks of the 1850s. The distinguished Cuban social theorist, Fernando Ortiz, likewise proclaimed the criollo nature of Cuban identity in his influential work, Contrapunto Cubano (Cuban Counterpoint, 1940), which distinguished the indigenous, smallholder crop tobacco from the imported, plantation crop sugar. Ortiz also emphasized the African contributions by comparing Cuban national identity to the criollo dish ajiaco (Ortiz, 1993).

41 For a large segment of the Cuban middle class, intent on importing modernity from the United States, the criollo held little interest. Triay's work remained influential to later cookbook authors, but they eschewed any ideological orientation and significantly reduced the presence of local recipes. European dishes were preferred, and racist references to white supremacy squeezed out Ortiz's more inclusive views, even in one volume that contained an essay by the prominent scholar (Folch, 2008).

The most important work of pre-revolutionary cookbooks was unquestionably Nitza Villapol and Martha Martínez's Cocina al minuto (Cooking in a Minute, 1956). Born in New York City in 1923 to Cuban exile parents, Villapol received a teaching degree. Widely considered to be the Cuban Julia Child, she published cookbooks and had a popular television program already in the 1950s. Her book, intended for the Cuban middle classes, and those who aspired to the American way of life, was carried into exile after 1960 by countless middle class families.

Ironically, Villapol remained in Cuba and became a supporter of the revolution, dedicating her television show and cookbooks to nourishing a socialist society. Marisela Fleites-Lear (2012) has recently argued that while the 1956 edition of Cocina al minuto was clearly a commercial cookbook, a revised edition published in 1980 represented a community cookbook that sought to build a new inclusive, revolutionary society, in part by proclaiming the African roots of the national identity. The 1980 edition eliminated Spanish dishes such as gazpacho and instead offered a practical discussion 
of hearty grains and root vegetables, while the conclusion, following Ortiz, declared ajiaco to be the national dish.

The interactions between local and cosmopolitan cooking still persisted even after the Cuban Revolution. Agricultural policy under Castro shifted direction on several occasions, going from a land reform policy that encouraged smallholdings to the Soviet productionist approach of the "ten million ton harvest" in 1970. Growing ties to the Communist Bloc also resulted in new forms of cosmopolitanism through the importation of rice cookers from China and grains from Eastern Europe, although these unfamiliar foods were often looked on with disdain by Cubans. Villapol therefore offered advice to women for localizing these imports, for example, making criollo tamales out of Russian oats (Fleites Lear, 2012). Dawdy (2002) points out, moreover, that smallholders remained the primary basis for food production on the island.

The political upheavals of twentieth century Latin America defy easy periodization, as do the culinary expressions of these social transformations. What is clear from this review of three nations is that food policy and culinary literature were important areas of contention between social groups seeking to establish their claims. While governments often based their food policies on maximizing productivity to ensure national health, it may have been the more equitable distribution of food carried out by the Cuban communist party that achieved the best health outcomes, even at times of widespread shortages. Examining these class conflicts around food therefore hold great value for future research.

\section{Conclusion}

National cuisines have emerged in Latin America through a complex interaction between local and global discourses and ingredients. The term criollo has been crucial to this process, yet its meanings and values have been deeply contested. Of the three nations considered here, Cuba was the first to proclaim a national cuisine based on criollo foods, even before the island became an independent nation. Criollo foods in Cuba were quickly defined, with attention to regional differences, around the category of viandas. While many of these root vegetables were of indigenous origin, the global was also subsumed within the category of criollo by way of African products. Argentina adopted the term criollo to refer to local foods, although the category was even looser, encompassing Hispanic pucheros and empanadas as well as indigenous maize and squash soups. The most basic expression of criollo food has been the asado, which has become associated with a mythical gaucho past, even though it is practiced most commonly in urban settings by otherwise European-identifying middle classes. In this group, Mexico stands as the outlier as a national cuisine with deep criollo sympathies that steadfastly refuses the term. There are a number of possible reasons for this : Mexican foods are generally speaking less European than those of Cuba and Argentina. Moreover, in Mexico, the word criollo has retained more of its colonial meaning of Spaniards born in the Indies as opposed to peninsulares while in Cuba and Argentina it became a more generic term for native. Whatever the reason, the nationalist chefs of the so called Nueva Cocina Mexicana have cloaked a largely European cuisine in the mantle of Aztec and Maya emperors, while living Indians have been distanced, or at best, retained as a folkloric curiosity. 
47 A final conclusion that emerges from this essay is the importance of foreign influences on national cuisines and identities. Certainly the interplay between the global and the local has continued over the course of centuries, even as the particular nature of these exchanges has changed over time. Representations of the global, which were dominated by France in the eighteenth and nineteenth centuries, have shifted toward the United States in the twentieth century, although the elite connotations of French cuisine have never been matched by the fast food attached to North Americans. Indeed, Bak-Geller Corona's observation of the significance of Parisian publishing houses in developing Mexican culinary literature has modern parallels in cookbook authors such as Diana Kennedy (see also Ory, 1997). By the same token, Tobin suggests that the emergence of asado as a national symbol may well have been encouraged by foreigners looking for particular representations of the mythic gaucho. Just as cuisines develop historically through the interaction of the global and the local, so do identities.

\section{BIBLIOGRAPHIE}

AGUILAR-RODRÍGUEZ Sandra, « Nutrition and Modernity : Milk Consumption in 1940s and 1950s Mexico », Radical History Review, n 110, 2011, pp. 36-58.

ARCONDO Aníbal, Historia de la alimentación en Argentina. Desde los orígenes hasta 1920, Córdoba, Ferreyra Editor, 2002.

ARROM José Juan, «Criollo : Definición y Matices de un Concepto », Hispania, vol. 34, n² 2, 1951, pp. 172-76.

AYORA-DIAZ Steffan Igor, Foodscapes, Foodfields and Identities in Yucatán, New York, Berghahn, 2012.

BAUER Arnold J., Goods, Power, History : Latin America's Material Culture, Cambridge, Cambridge University Press, 2001.

BAK-GELLER CORONA Sarah, «Los recetarios 'afrancesados' del siglo XIX en México : La construcción de la nación Mexicana y de un modelo culinario nacional », Anthropology of Food, $\mathrm{n}^{\circ}$ 6. Disponible en ligne : http://aof.revues.org/index6464.html.

BRADING David A., The First America : The Spanish Monarchy, Creole Patriots, and the Liberal State, 1492-1867, Cambridge , Cambridge University Press, 1991.

CARRIZO de GANDULFO Petrona, El libro de Doña Petrona, Buenos Aires, Cia. Gral Fabril Financiera, $29^{\text {th }}$ ed., 1949.

CABRISAS Juan, Nuevo manual de la cocinera catalana y cubana, Barcelona, Planeta Singular, 1995 [1858].

CALDERÓN de la BARCA Fanny, Life in Mexico : The Letters of Fanny Calderón de la Barca, New York, Doubleday, edited by Howard T. Fisher and Marion Hall Fisher, 1966. 
CAMOU HEALY Ernesto, «La nostalgia del rancho : Notas sobre la cultura urbana y la carne asada » in Shoko DOODE and Emma-Paulina PÈREZ (eds.), Sociedad, economía y cultura alimentaria, Hermosillo, CIAD, 1994, pp. 431-29.

CARA Ana C., «The Poetics of Creole Talk: Toward an Aesthetic of Argentine Verbal Art », Journal of American Folklore, vol. 116, n 459, 2003, pp. 36-56.

CARNEY Judith, Black Rice : The African Origins of Rice Cultivation in the Americas, Cambridge, Harvard University Press, 2001.

CICERCHIA Ricardo, Historia de la vida privada en la Argentina, Buenos Aires, Troquel, 1998.

DAWDY Shannon L., « La Comida Mambisa : Food, Farming, and Cuban Identity, 1839-1999 », New West Indian Guide, vol. 76, $\mathrm{n}^{\circ}$ 1-2, 2002, pp. 47-80.

EARLE Rebecca, The Body of the Conquistador : Food, Race and the Colonial Experience in Spanish America, 1492-1700, Cambridge, Cambridge University Press, 2012.

FERGUSON Priscilla-Parkhurst, Accounting for Taste : The Triumph of French Cuisine, Chicago, University of Chicago Press, 2004.

FLEITES-LEAR Marisela, « Mirrors in the Kitchen : The New Cuban Woman Cooks Revolutionarily », Food, Culture, and Society, vol. 15, $n^{\circ} 2,2012$, pp. 241-60.

FLORESCANO Enrique, Memory, Myth, and Time in Mexico : From the Aztecs to Independence, Austin, University of Texas Press, 1994.

FOLCH Christine, «Fine Dining: Race in Prerevolution Cuban Cookbooks », Latin American Research Review, vol. 43, n², 2008, pp. 205-23.

FREEDMAN Paul, Out of the East : Spices and the Medieval Imagination, New Haven, Yale University Press, 2008.

FURLONG Guillermo, Historia social y cultural del Río de la Plata, vol. 2, Buenos Aires, Tipográfica Editora Argentina, 1969.

GABACCIA Donna and ALDRICH Jane, " Recipes in Context : Solving a Small Mystery in Charleston's Culinary History ", Food, Culture \& Society, vol. 15, n² 2, 2012, pp. 197-221.

GARCÍA CUBAS Antonio, El libro de mis recuerdos, México, Secretaría de Educación Pública, 1946. GORRITI Juana Manuela, Cocina ecléctica, Buenos Aires, Aguilar, edited by María Rosa Lojo, 1999 [1890].

JUÁREZ LÓPEZ José Luis, Nacionalismo culinario : La cocina mexicana en el siglo XX, México, CONACULTA, 2008.

LEGRAN José P., Nuevo manual del cocinero cubano y español, Habana, La Intrépida, 1858. Disponible en ligne :

http://merrick.library.miami.edu/cdm/compoundobject/collection/chc9999/id/5379.

LOMBARDO de MIRAMÓN Concepción, Memorias, México, Editorial Porrúa, 1980.

MILANESIO Natalia, « Food Politics and Consumption in Peronist Argentina », Hispanic American Historical Review, vol. 90, n 1, 2010, pp. 75-108.

MOLINA ENRÍQUEZ Andrés, Los grandes problemas nacionales, México, Editorial Era, 1978 [1909]. MOYA José C., «A Continent of Immigrants : Postcolonial Shifts in the Western Hemisphere ", Hispanic American Historical Review, vol. 86, n 1, 2006, pp.1-28. 
MOYA José C., Cousins and Strangers : Spanish Immigrants in Buenos Aires, 1850-1930, Berkeley, University of California Press, 1998.

OCHOA Enrique C., Feeding Mexico : The Political Uses of Food Since 1910, Wilmington, Scholarly Resources, 2000.

ORTIZ Fernando, « Los factores humanos de la cubanidad » in Isaac BARREAL (ed.), Etnia y sociedad, Havana, Editorial de Ciencias Sociales, 1993, pp. 1-20.

ORY Pascal, « Gastronomy » in Pierre NORA (ed.), Realms of Memory: The Construction of the French Past, vol. 2 (Traditions), New York, Columbia University Press, 1997, pp. 442-67.

PAYNO Manuel, Los Bandidos de Río Frío, México, Porrúa, 24 $4^{\text {th }}$ ed., 2004 [1891].

PÉREZ Louis A. Jr., On Becoming Cuban : Identity, Nationality, and Culture, Chapel Hill, University of North Carolina Press, 1999.

El Perseguido (Buenos Aires), January 1, 1892.

PILCHER Jeffrey M., Planet Taco : A Global History of Mexican Food, New York, Oxford University Press, 2012.

PILCHER Jeffrey M., ¡Que vivan los tamales! Food and the Making of Mexican Identity, Albuquerque, University of New Mexico Press, 1998.

PITE Rebekah E., Creating a Common Table : Doña Petrona, Women, and Food in the Making of Modern Argentina, Chapel Hill, University of North Carolina Press, (forthcoming).

PITE Rebekah E., « Entertaining Inequalities : Doña Petrona, Juanita Bordoy, and Domestic Work in Mid-Twentieth-Century Argentina », Hispanic American Historical Review, vol. 91, n 1, 2011, pp. 97-128.

PRIETO Guillermo, Memorias de mis tiempos, 1828 a 1840, México, Librería de la Vda. de C. Bouret, 1906.

REMEDI Fernando J., Los secretos de la olla. Entre el gusto y la necesidad : la alimentación en la Córdoba de principios del siglo XX, Córdoba, Centro de Estudios Históricos, 1998.

RODRÍGUEZ Jaime E., The Independence of Spanish America, Cambridge, Cambridge University Press, 1998.

RUGGIERO Kristin H., " The Legacy of Samiento's Civilization and Barbarism in Modern Argentina » in Joseph T. CRISCENTI (ed.), Sarmiento and His Argentina, Boulder, Lynne Rienner Publishers, 1993, pp. 183-93.

SCHÁVELZON Daniel, Historias del comer y del beber en Buenos Aires. Arqueología histórica de la vajilla de mesa, Buenos Aires, Aguilar, 2000.

SCOTT Nina M., "Juana Manuela Gorriti's Cocina ecléctica : Recipes as Feminine Discourse » in Anne L. BOWER (ed.), Recipes for Reading : Community Cookbooks, Stories, Histories, Amherst, University of Massachusetts Press, 1997, pp. 189-99.

TABLADA José Juan, La feria de la vida, México, Ediciones Botas, 1937.

TOBIN Jeffrey, « Todo mito gauchesco que camina va a parar al asador porteño : El asado y la identidad nacional porteña » in María Cristina PONS and Claudia SORIA (eds.), Delirios de grandeza. Los mitos argentinos: Memoria, identidad, cultura, Rosario, Beatriz Viterbo, 2005, pp. 211-28. 
TRIAY José E., Manual del cocinero criollo, Habana, La Moderna Poesía, 1914 (1903). Disponible en ligne : http ://merrick.library.miami.edu/cdm/compoundobject/collection/chc9999/id/5151/ $\mathrm{rec} / 1$.

VELÁZQUEZ de LEÓN Josefina, Platillos regionales de la República Mexicana, México, Ediciones Josefina Velázquez de León, 1946.

VILLAPOL Nitza and MARTÍNEZ Martha, Cocina al minuto, La Habana, Talleres Roger A. QueraltArtes Gráficas, 1956.

WILK Richard, Home Cooking in the Global Village : Caribbean Food from Buccaneers to Ecotourists, Oxford, Berg, 2006.

\section{RÉSUMÉS}

Cet article étudie les diverses interprétations sur la cuisine locale et internationale en Argentine, à Cuba et au Mexique. Le $19^{\text {ème }}$ siècle en Amérique latine a souvent été perçu comme une époque libérale pendant laquelle les produits importés étaient très estimés. À l'inverse, le $20^{\text {ème }}$ siècle est plutôt vu comme une période durant laquelle le populisme nationaliste s'approprie la culture locale et refuse, du moins jusqu'au début de l'époque néolibérale, l'importation de produits européens et nord-américains. Or, pendant que les libéraux cherchent à compenser leur sophistication internationale par leur affection patriotique pour le pays, la classe moyenne révolutionnaire développe ses propres aspirations cosmopolites. Il est donc plus aisé d'apprécier l'évolution de ces significations en étudiant les différents usages du terme criollo qui font référence aux cuisines locales. Cet article défend la thèse selon laquelle les cuisines nationales ont émergé en l'Amérique latine, non pas du rejet de l'international et la préférence du local, mais plutôt de la fusion des deux, tout en créant une sensibilité culinaire qui combine à la fois, le patriotisme et cosmopolitisme, et dont le but n'est autre que la distinction sociale.

This essay examines the changing meanings of local and global foods in Argentina, Cuba, and Mexico. Nineteenth-century Latin America is often viewed as a period of liberal ascendancy when imported goods were highly valued, while on the contrary, the twentieth century is seen as a time of populist nationalism that embraced local culture and, at least until the neoliberal era, rejected European and North American imports. Nevertheless, liberals sought to balance their international sophistication with a patriotic affection for the local, while revolutionary middle classes aspired to their own versions of cosmopolitanism. These changing meanings become particularly evident through an examination of the divergent usages of the term "criollo" to refer to local foods. The paper argues that national cuisines emerged throughout Latin America not from the rejection of the global in favor of the local but rather through a blending of the two in a culinary sensibility that combined patriotism and cosmopolitanism in pursuit of social distinction.

El presente ensayo examina la significación de las cocinas locales y globales en Argentina, Cuba y México. El siglo XIX se percibe en América Latina como una época liberal durante la cual los bienes importados eran sobrevalorados, mientras que en el siglo XX, el nacionalismo populista rechaza las importaciones europeas y norteamericanas y revalora por el contrario, al menos hasta la llamada época neoliberal, la cultura local. Sin embargo, los liberales también defendieron el patriotismo local, mientras las clases medias revolucionarias buscaban apropiarse de un cosmopolitismo global. Ambos procesos pueden ser observados a través de las diferentes acepciones de la palabra "criollo", utilizada para designar a las comidas locales. Desde un punto de vista culinario, el argumento central de este ensayo sugiere que las cocinas nacionales 
emergieron en América Latina por la combinación de dos factores, la resistencia a lo foráneo y la preferencia de la cocina local, a través del patriotismo y el cosmopolitismo como fuentes de distinción social.

INDEX

Palabras claves : comida, América Latina, cultura material, nacionalismo, cosmopolitismo Mots-clés : cuisine, Amérique latine, culture matérielle, nationalisme

Keywords : cuisine, Latin America, material culture, nationalism

\section{AUTEUR}

\section{JEFFREY M. PILCHER}

Professor of history at the University of Minnesota. His most recent books are Planet Taco: A Global History of Mexican Food and The Oxford Handbook of Food History (2012). pilcherjatumnpointedu 